north of the Caledonian Canal, it seems to me that thrs is extremely improbable, as along the two traverses we made-one from Garve to Ullapool, the other from Laxford to Lairg-the prevalent dips are eastward, and the upper quartzites forming the elevations of Ben Dearig and Ben More are of great thickness. One may therefore assume that the Laurentian gneiss (even in the absence of the Cambrian sandstone) is deeply buried beneath these beds and their succeeding schists. The region of the Grampians of Aberdeenshire, on the other hand, is of great extent, and until it has been explored by the officers of the Geological Survey it would be injudicious (as it appears to me) to come to any opinion on the subject. EDWARD HULL

Geological Survey Office, Hu ne Street, Dublin, January 18

\section{Geological Climates}

Having considered the effects of Mr. Wallace's proposed redistribution of land and water, intended to raise the mean annual temperature of Bournemouth $15^{\circ}$ or $20^{\circ} \mathrm{F}$. above its present amount, I now, with your permission, shall say a few words on some minor questions, which have arisen during our discussion of the difficult problem of Geological Climates.

1. The Clump of Bamboos at Cooper's Hill Engineering College. - Prof. McLeod has kindly forwarded me a specimen of the foliage of the bambos now growing in his garden, and has promised to send me the fruit when it ripens.

My botanical friends cannot decide its species, with certainty, from the foliage alone, without the seeds, but think that it, probably, is the bamboo called Thamnocalamus Falconeri, formerly called Arundinaria falcata (not Arundinacea) and also called Bambusa gracilis. If this opinion be correct my rejection of its evidence in favour of Cooper's Hill now having the climate of "torrid India" was also correct; for this bamboo is one of the hardiest of the "hardy bamboos" growing in the Himalayas, as high as the limit of perpetual snow, and being exposed, at night and in winter, to extremes of cold, which are never experienced in the British Islands. Whether our summer: are hot enough to ripen its seeds, and fully acclimatise it amongst $u=$, remains to be seen.

It is a suggestive fact that at Fota, in the Cove of Cork, where it grows in clumps 20 feet in circumference, from each of which spring over 400 canes reaching a height of 25 feet; the seeds ripen with difficulty and take a long time to germinate, some two months elapsing before they come through the soil, even in a temperature of $70^{\circ} \mathrm{F}$.

2. The Moreton Bay Pine at Bournemouth.-Mr. William Ingram's letter, stating that an individual of this species, surrounded with "wooded heights" about it, has lived for forty years in Leicestershire, and attained a height of 35 feet, shows what the gardener's skill can accomplish in protecting a sub-tropical tree from the injurious effects of English winters, but throws no light whatever upon the possibility of the Moreton Bay pine living spontaneously in this country.

In order to do so it must ripen its fruit and produce seedlings, which (as I am informed) it cannot possibly do with the moderate heat of our cool summers.

3. Tertiary Climates in England.-Mr. Gardner states, that independently of the evidence afforded by the Moreton Bay pine, the Tertiary fossil plants of the Eocene require an increase of temperature of, at most, $20^{\circ} \mathrm{F}$

When we add to this that the London clay contains true Crocodiles, true Palms, many species of Nautilus, of Volutes, and large species of $C_{y}$ proa, we may be certain that $20^{\circ} \mathrm{F}$. increase of temperature is the very minimum required.

The question of importance is, whence did this required heat come from? This is a question of number and magnitude, and not of mere " naturalist talk." This question cannot be settled by redistributions of land and water, nor by repeating continually the assertion that all former causes of change of climate were the same as existing causes, not only in kind, but in degree.

Trinity College, Dublin, January $\mathbf{r}_{4}$ SaMUEl Haughton

I AGREE with Prof. Haughton in his conclusion that no increase in the quantity of water sent into the Arctic Ocean by currents like the Gulf Stream would make much practical difference in the Arctic climate, though not altogether for his reasons. I think the question of total quantities of heat is irrelevant, and that the extent of glaciation and the distribution of plants and animals are almost exclusively determined by suminer temperatures.

Respecting the distribution of plants and animals, I believe this is the general testimony of naturalists, and it is certainly confirmed by Nordenskjöld's observations on the Siberian flora. Respecting glaciation, I rely for proof on the well-known fact that the extent of perpetual snow on mountains - in other words, the height of the snow-line-depends, not on mean temperature, but on summer temperature.

If this is true it shows that no change in the ocean currents would make much difference; for a glance at Doves isothermal lines for July and January shows that the effect of the Gulf Stream on the temperatures of Europe and Asia and the Arctic Ocean is chiefly confined to wirter. The late Mr. Hopkins, in his well-known paper on changes of climate (Geological Society, December, 185I) estimated that the effect of the Gulf Stream on the July climate of London is null.

Old Forge, Dunmurry, Co. Antrim, January I 7

Prof. Whitney on the Glaciation of British Columbia

It must be gratifying to all geologists interested in the western part of America to find that a portion of the general results of the work of the Californian Survey is at length being published under the auspices of the Museum of Comparative Zoology at Harvard College, Prof. Whitney's "Auriferous Gravels of the Sierra Nevada" being now supplemented by the first part of a volume on the "Climatic Changes of Later Geological Times," dealing chiefly with the evidences of glaciation on the Pacific slope. No one will question Prof Whitney's observations and deductions on this subject when he deals with that portion of the region with which he is personally familiar, especially as these are in substantial agreement with the already. published facts of Clarence King. The general result arrived at in the areas of Whitney's and King's surveys is that comparatively only a very small portion of the highest ranges of mountains has ever been covered with glaciers, and that there has never been in this region anything like a northern drift period or a transportation of material in any given direction independent of the present topographical features of the country.

This accords also with the statement published by Prof. Whitney in r866 (Proc. Col. Acad. Sci. vol. iii. p. 27I) as to the absence of glacial traces of a general character from California, but-as it appears to me unfortunately - a clause was added to this statement embracing in the generalisation the whole north-western extension of the Cordillera region. Now in $\mathrm{r} 866$, as Prof. Whitney himself says, almost nothing was definitely known of the coast north of Oregon, and for that portion of it included in the province of British Columbia I have since maintained, as the results of observation, that there is con clusive proof of the occurrence of a period of general glaciation comparable in its effects with that of eastern North America (see Quart. Journ. Geol. Soc. vol. xxxiv. p. 89; Canadian Naturalist, vol. viii. No. 7 ; vol. ix. No. I ; also the following Reports of the Geological Survey of Canada, 1875-76, p. 261 ; 1877-78, p. I33 B. ; I878-79, p. 89 B.) In summarising and dis cussing the evidences of glaciation in British Columbia however Prof. Whitney still thinks it necessary to support the correctness of his paper of 1866 . As Prof. Whitney's volume "appears to be intended as a general, and, so far as the facts now known go, final review of the glaciation of the Pacific slope, and professes to contain "all that is necessary to set forth in regard to the former glaciation of the western side of the American continent," it may not be amiss to state that in my view the account given of the evidences of glaciation in British Columbia is in some cases insufficient, and that in the interpretation of other points misconceptions as to the nature of - the facts have arisen. The tendency of the whole treatment of the subject is to minimise the glacial phenomena of the northern part of the coast and assimilate the conditions there found to those of California, which appear to me to be essentially different. (For a comparison of these see "Travelling Notes on the Surface Geology of the West Coast," Canadian Naturalist, vol. viii. No. 7.)

To criticise minutely the numerous features which seem open to such treatment in the account of this region, with which seven seasons' work in connection with the Boundary Commission and Geological Survey of Canada has rendered me familiar, would require a lengthened article, and would at best be an ungracious task. I will therefore touch on a few salient points only. 